\title{
Herbal Snake Bite Remedies of Irula Tribal People of Kancheepuram District, Tamil Nadu, India
}

\author{
K. Senthilkumar ${ }^{1 *}$, P. Mathialagan ${ }^{2}$ and C. Manivannan ${ }^{3}$
}

\author{
${ }^{1}$ Department of Wildlife Science, ${ }^{2}$ Department of Veterinary and Animal Husbandry Extension \\ Education, Madras Veterinary College, TANUVAS, Chennai-600 007, India \\ ${ }^{3}$ University Publication Division, \\ Tamil Nadu Veterinary and Animal Sciences University, Chennai-51, India
}

*Corresponding author

\section{A B S T R A C T}

Several scientific studies are in progress using modern scientific tools based on the lead from the folkloric and herbal uses for formulating new western medicine. The present

Keywords

Snake bite remedies, Medicinal plants, Herbs,

Digital

documentation, Irula tribes

Article Info

Accepted:

06 June 2018

Available Online:

10 July 2018 study involves the identification, enumeration and utilization of medicinal flora among the Irula tribes of Kancheepuram district of Tamil Nadu and a record of the endangered medicinal plants in the study area. A total number of 30 respondents of three villages, viz., Chenneri, Orathur and Kunavakkam-Kollamedu were selected by purposive random sampling. The ethnobotanical data were collected using questionnaire, interviews and discussions with local tribal people. Digital documentation of the case studies of animal and human snakebites was recorded for reference. The Knowledge about the medicinal plants has been transmitted orally from generation. The investigation revealed that there are about 27 species of plants to treat snake bite. Voucher specimens of medicinal plants used was prepared for documentation and dissemination of ethno veterinary practices pertaining to snake bite. The respondents used different treatment methods including suck, cut and bind followed by application of different herbal plants identified in this study as root poultices and application of plant leaf juice directly in the snake bite wound. The study revealed that the tribals rely on medicinal plants for snake bite treatment than modern medicine.

\section{Introduction}

Snake bite is a significant cause of morbidity and mortality in many parts of the world (Warrell, 1996). India has rich assortment of snake fauna, of which only 242 species have been identified including poisonous or harmful species. The four major species of venomous snakes ubiquitous in India known as "Big four" are considered responsible for life-threatening envenomation around the country. These include- Indian cobra (Naja naja), the common krait (Bungarus caeruleus), the Russell's viper (Daboia russelii) and the Sawscaled viper (Echis carinatus). Up to $80 \%$ of snakebite victims first consult traditional practitioners before visiting a medical centre (Snow et al., 1994). 
Direct testimony from victims attests to the perceived powers of traditional treatments. The success of traditional healers is vaguely understood to be partly due to the occult and sometimes mystical nature of their practice.

However, a medico-ethanobotanical survey among the Irula tribes in some areas of Tamil Nadu is reported by Revathi and Parimelazhagan, (2010) and Murugesan et al (2005). Anita Jain et al (2011) reported snakelore and indigenous snakebite remedies practiced by some tribal's of Rajasthan. But no study is reported in India with special emphasis on snake bite herbal therapy persisting among the Irula tribes of Kancheepuram district. Hence an attempt is made to examine their practices, which remain incompletely known, this study pays attention to herbal and some non-herbal therapies used by traditional healers of Irula society in managing snakebites among humans and livestock in the study area.

Total population of the Irulas is about 56,000 who are spread over in Kancheepuram and Thiruvallur districts. This is second largest tribal community in Tamil Nadu. (Prakash Rao, 2007).

Irulas are not living on the hills but depended on forest for their traditional activities. Their main occupation is snake catching (Opilli, 2009). The Irulas are practicing various techniques and herbal therapy to get prevented by snake bites.

In view of the importance of traditional medicine which provides health services to $75-80 \%$ of the world population, increased demand of herbal drugs by the pharmaceuticals and depleting natural plant resources, it is high time to document the medicinal utility of less known plants available in remote areas of country (Zaidi and Crow 2005).
Keeping these points in mind, a study was undertaken with the following objectives:

1. To document the indigenous knowledge through ethno botanical studies.

2. To digital documentation of case studies of the animal and human snake bites in the study area

To prepare voucher specimens of medicinal plants for documentation and dissemination of ethno veterinary practices pertaining to snake bite.

\section{Materials and Methods}

\section{Selection of study area}

The exact study area is Kancheepuram district. Kancheepuram district is situated on the northern East Coast of Tamil Nadu and is adjacent by Bay of Bengal and Chennai city and is bounded in the west by Vellore and Thiruvannamalai district, in the north by Thiruvallur district and Chennai district, in the south by Villuppuram district in the east by Bay of Bangal. It lies between $11^{\circ} 00^{\prime}$ to $12^{\circ}$ $00^{\prime}$ North latitudes and $77^{\circ} 28^{\prime}$ to $78^{\circ} 50^{\prime}$ East longitudes. The district has a total geographical area of 4393.37 Sq.Kms and coastline of $57 \mathrm{Kms}$. Very few ethnobotanical works have been done in this area with Irula tribes.

\section{Sample design}

The ethnobotanical data were collected using questionnaire, interviews and discussions in their local tribal people. A total number of 30 respondents of three villages Chenneri, Orathur and Kunavakkam-Kollamedu were interviewed on purposive random sampling, these included males and females that depended on plant as sources of medicines either for self- medication or for treating others. 
Among them, 56\% were males and 44\% females. Selected elders were used as key informants that could provide information on how the knowledge/practice of medicinal plant collection had changed over time. The species list was prepared based on the information collected from the key respondents (Table 1).

\section{Species identification}

The plant species were identified using the field guides: The Flora of the Tamil Nadu Carnatic Vol I-III K.M. Matthew, Flora of Tamil Nadu, India. Ser. 1: Analysis. vol. 3 (Mathew 1993). Photographs from the field guide were shown to the informants and were recorded.

\section{Results and Discussion}

The socio-economic characterisitics of the respondents are tabulated in the Table 1. In response to the query about the education level, only four women can read and write and the rest of them are illiterate.

The mass media exposure varies from high to low. Majority of the respondents are having medium level of extension agency contact. Only 5.67 per cent of the respondents are having dairy animals and majority of them are rearing backyard poultry.

The digital documentation of the case studies of the animal and human snake bites was also performed to select the herbs used to cure the snake bite.

In the present investigation 27 medicinal plants were used for the treatment of snakebite. And voucher specimen was prepared Folklore medicinal plants were arranged in Table 2 which represents their botanical names followed by the family, vernacular name.

Table.1 Socio-economic characteristics of the Irula Tribal people of

Kancheepuram District $(\mathrm{n}=30)$

\begin{tabular}{|c|c|c|c|c|}
\hline S.No. & Characteristic & Category & Frequency & Percentage \\
\hline 1 & Age & $\begin{array}{l}\text { Old } \\
\text { Middle } \\
\text { Young }\end{array}$ & $\begin{array}{l}17 \\
9 \\
4\end{array}$ & $\begin{array}{l}56.67 \\
30.00 \\
13.33\end{array}$ \\
\hline 2 & Education & $\begin{array}{l}\text { Illiterate } \\
\text { Can read only } \\
\text { Can read and Write }\end{array}$ & $\begin{array}{l}26 \\
0 \\
4\end{array}$ & $\begin{array}{l}86.67 \\
13.33\end{array}$ \\
\hline 3 & $\begin{array}{l}\text { Mass Media } \\
\text { Exposure }\end{array}$ & $\begin{array}{l}\text { Low } \\
\text { Medium } \\
\text { High }\end{array}$ & $\begin{array}{l}14 \\
5 \\
11\end{array}$ & $\begin{array}{l}46.67 \\
16.67 \\
36.67\end{array}$ \\
\hline 4 & $\begin{array}{l}\text { Contact with } \\
\text { Extension } \\
\text { Agency }\end{array}$ & $\begin{array}{l}\text { Low } \\
\text { Medium } \\
\text { High }\end{array}$ & $\begin{array}{l}11 \\
13 \\
6\end{array}$ & $\begin{array}{l}36.67 \\
43.33 \\
20.00\end{array}$ \\
\hline 5 & Herd Size & $\begin{array}{l}\text { Small ( } \leq 4 \text { animals) } \\
\text { Large ( }>4 \text { animals) } \\
\text { Poultry birds }\end{array}$ & $\begin{array}{l}2 \\
\text { Nil } \\
21\end{array}$ & $\begin{array}{l}6.67 \\
\text { Nil } \\
70.00\end{array}$ \\
\hline
\end{tabular}


Int.J.Curr.Microbiol.App.Sci (2018) 7(7): 425-438

Table.2 List of medicinal plants used for snake bite by Irula Tribes

\begin{tabular}{|c|c|c|c|c|c|}
\hline S.No. & Name of the Species & Family & Common name & Picture & Parts used \\
\hline 1 & Corallocarpus epigaeus & Cucurbitaceae & $\begin{array}{l}\text { Aagasa Garuda } \\
\text { Kizhangu }\end{array}$ & & Tuber \\
\hline 2 & Rauvolfia tetraphylla & Apocynaceae & Nava konchi & & Leaves \\
\hline 3 & $\begin{array}{l}\text { Ruellia patula } \\
\text { (Leaves) }\end{array}$ & Acanthaceae & Silanthi Nayagam & & Leaves and Root \\
\hline
\end{tabular}


Int.J.Curr.Microbiol.App.Sci (2018) 7(7): 425-438

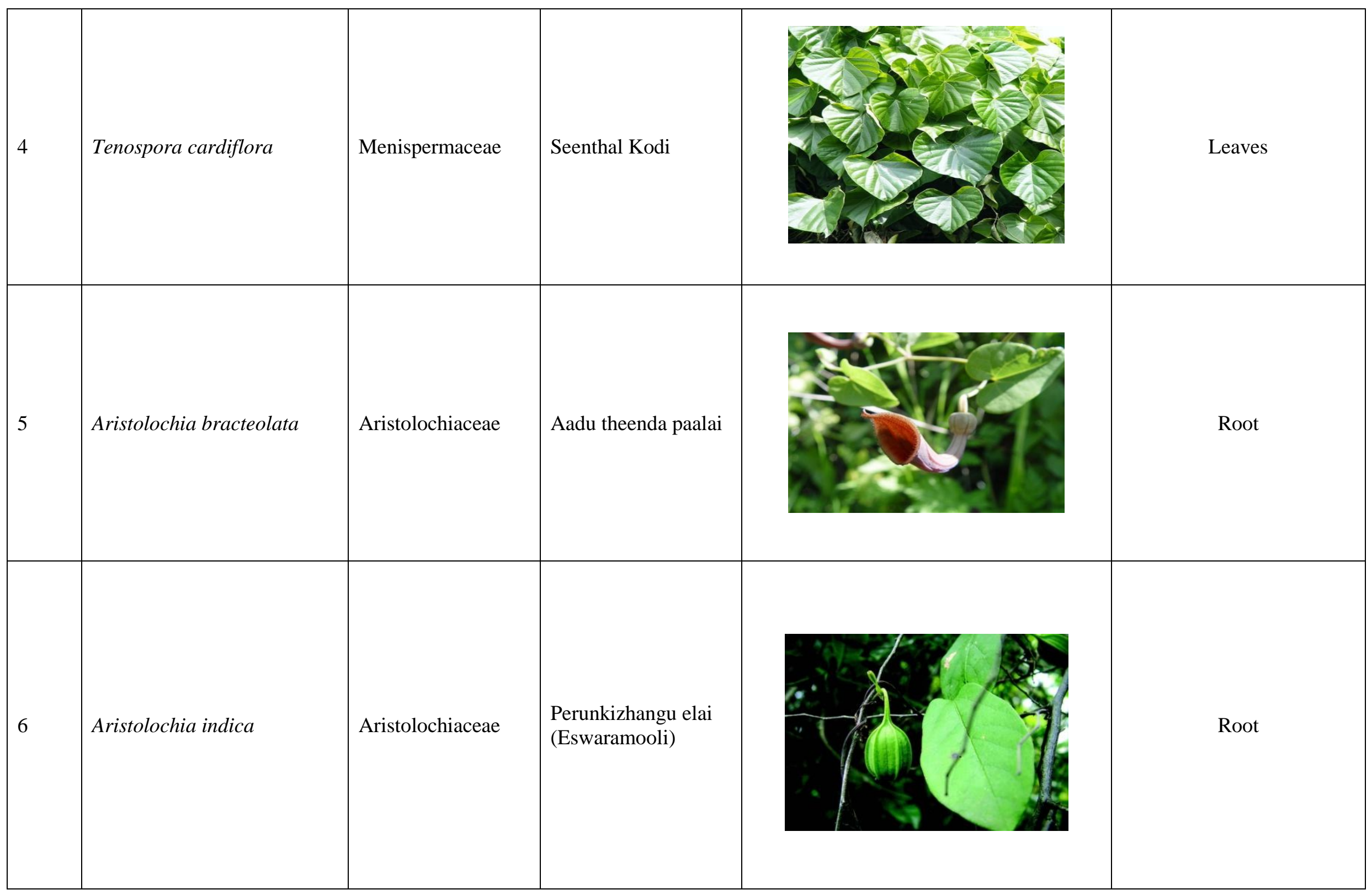


Int.J.Curr.Microbiol.App.Sci (2018) 7(7): 425-438

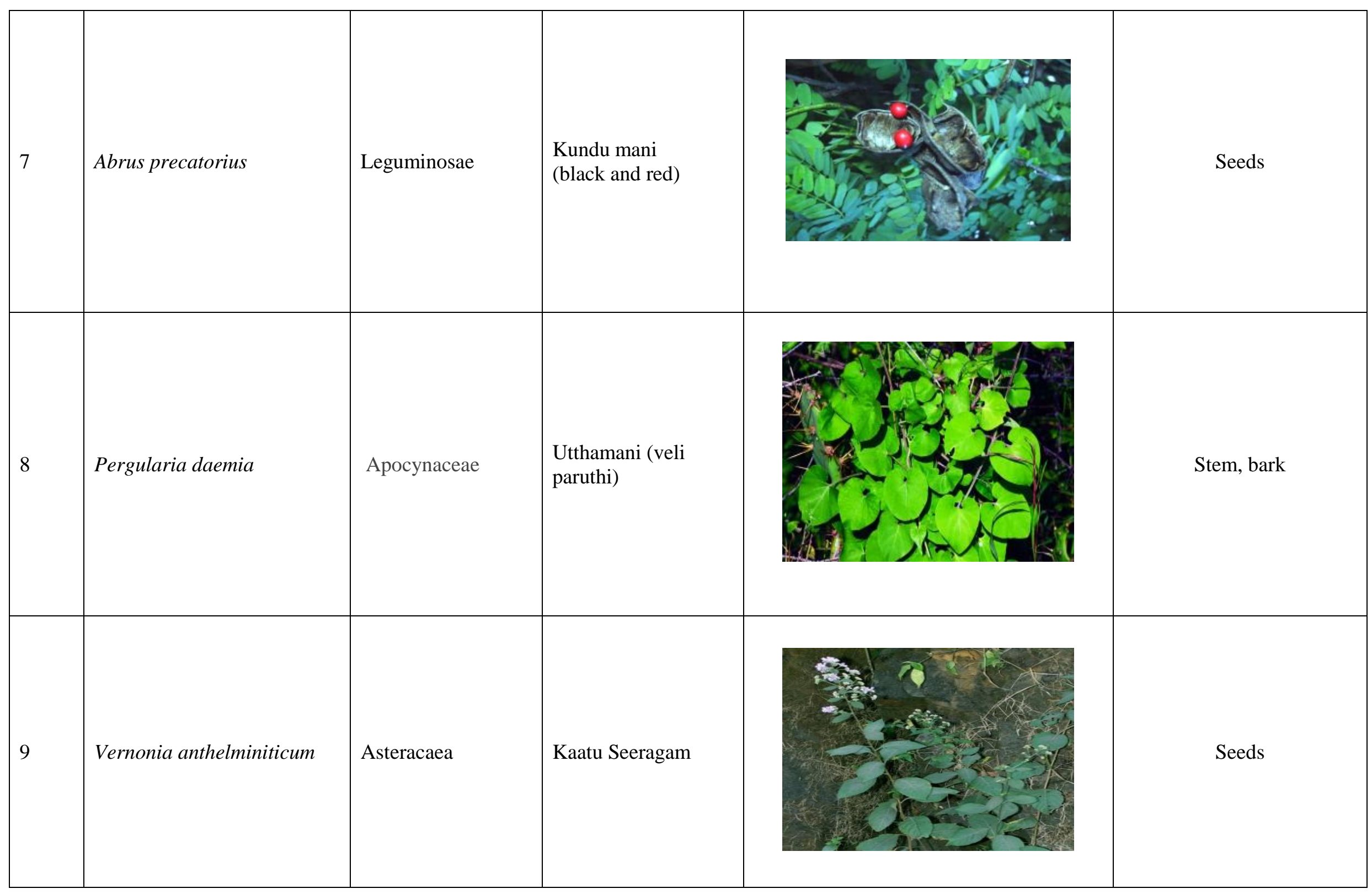


Int.J.Curr.Microbiol.App.Sci (2018) 7(7): 425-438

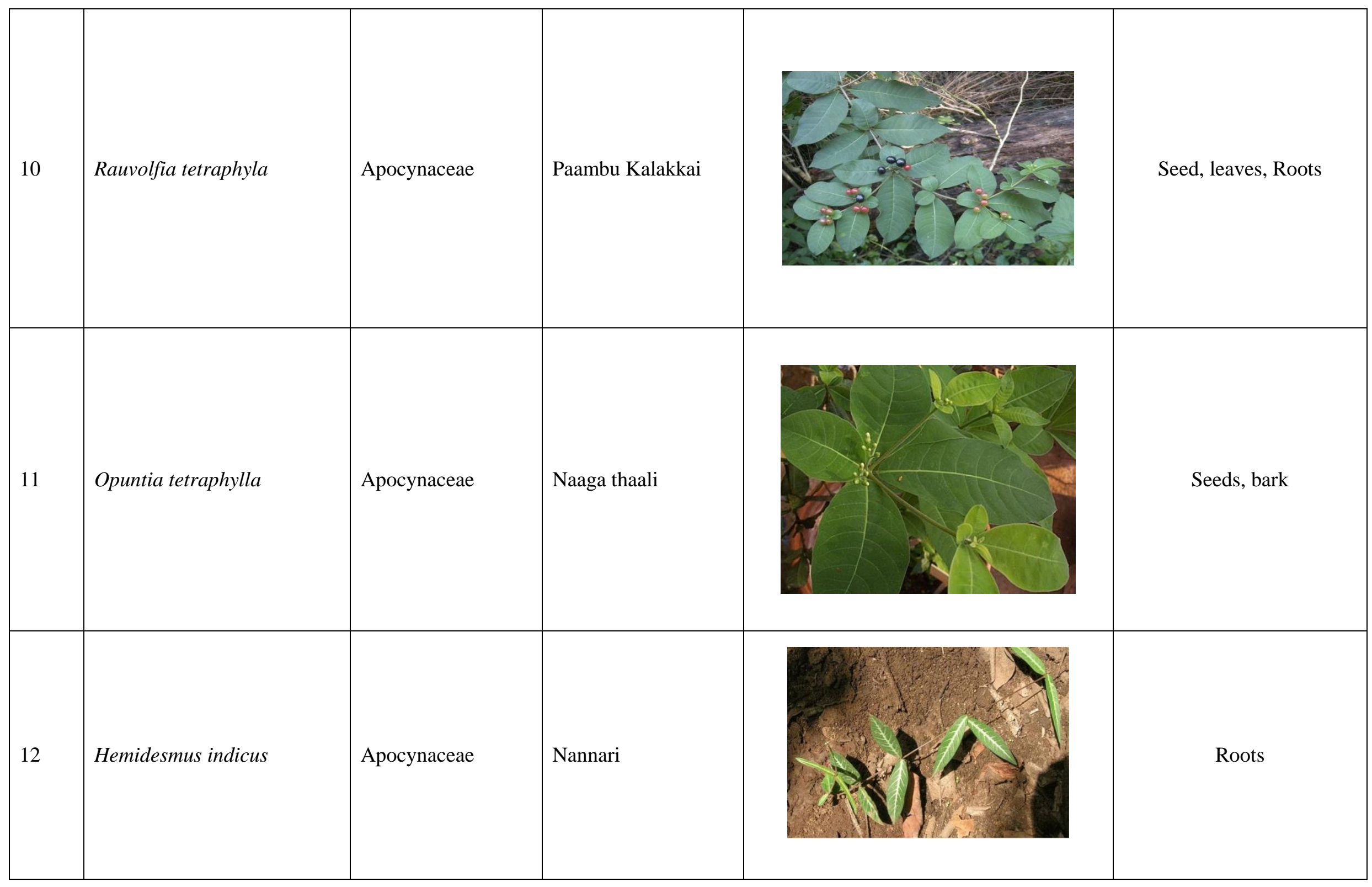


Int.J.Curr.Microbiol.App.Sci (2018) 7(7): 425-438

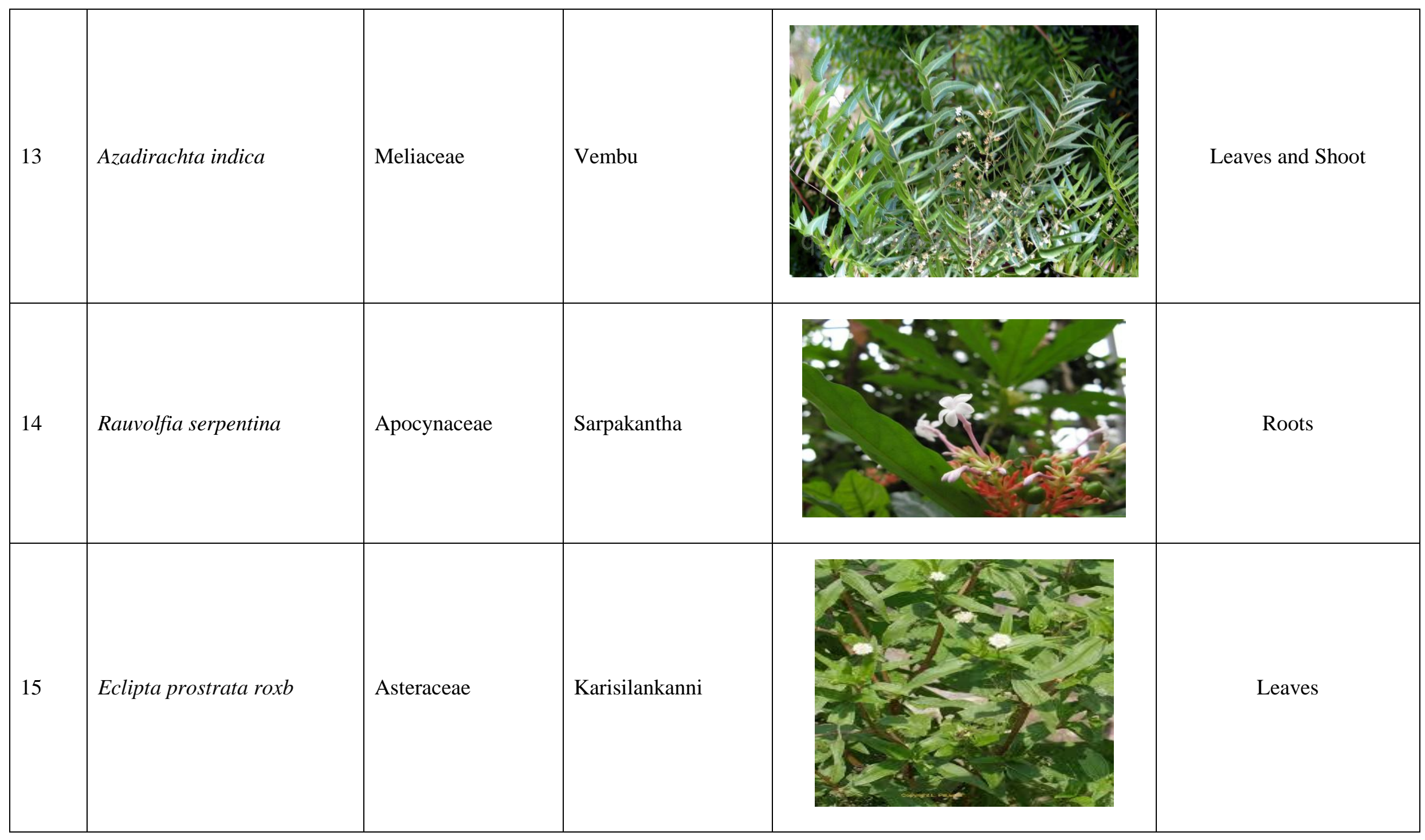


Int.J.Curr.Microbiol.App.Sci (2018) 7(7): 425-438

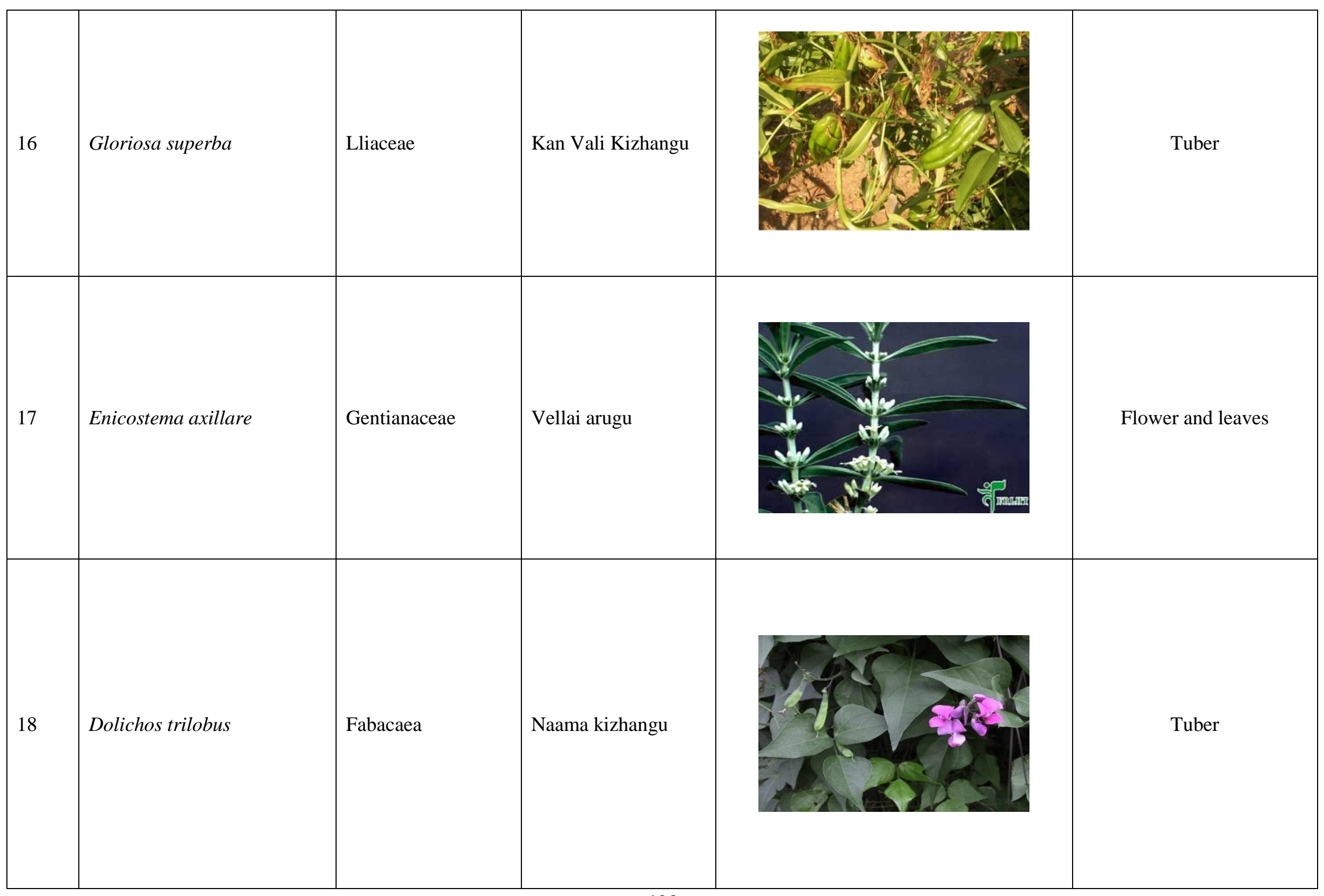


Int.J.Curr.Microbiol.App.Sci (2018) 7(7): 425-438

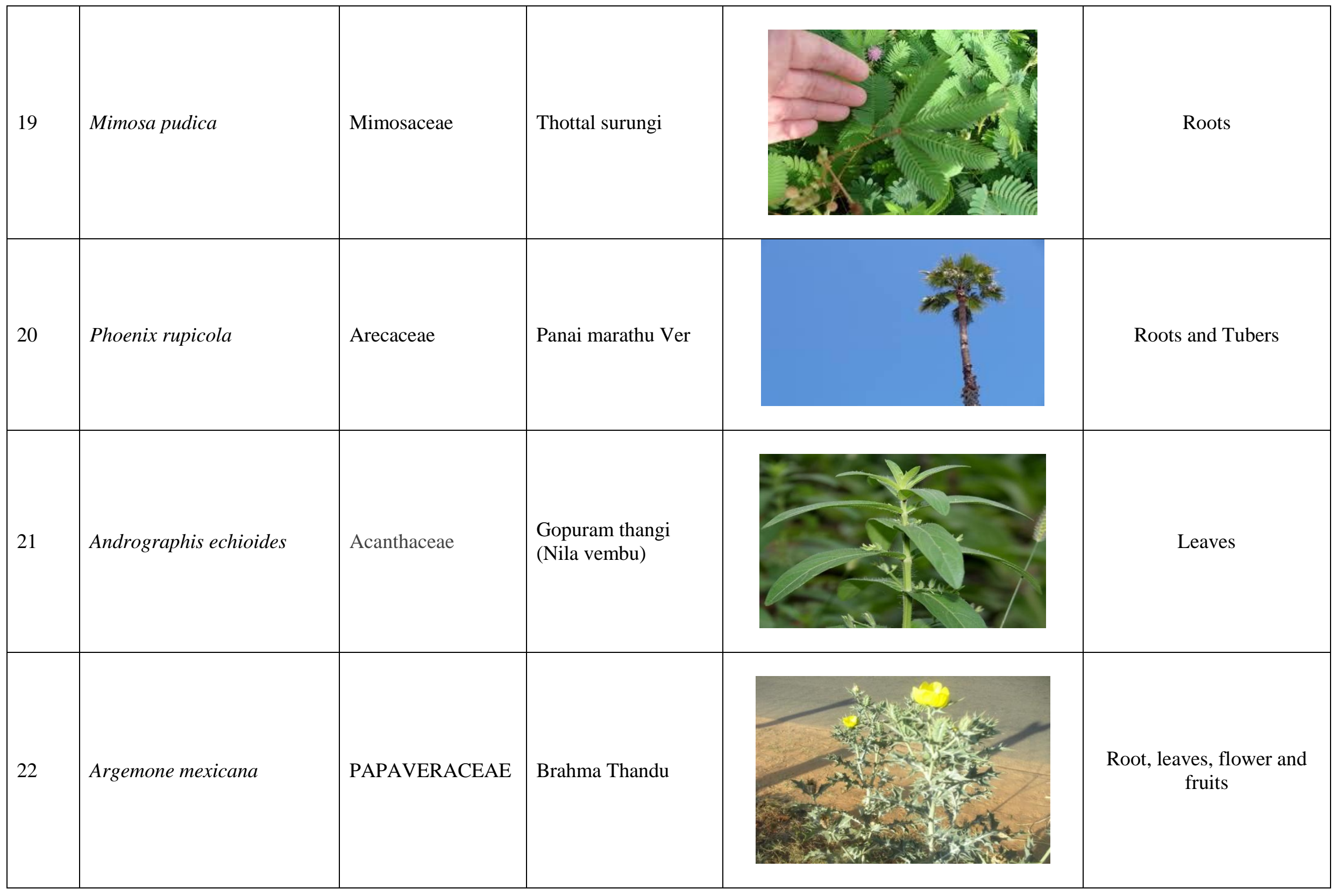


Int.J.Curr.Microbiol.App.Sci (2018) 7(7): 425-438

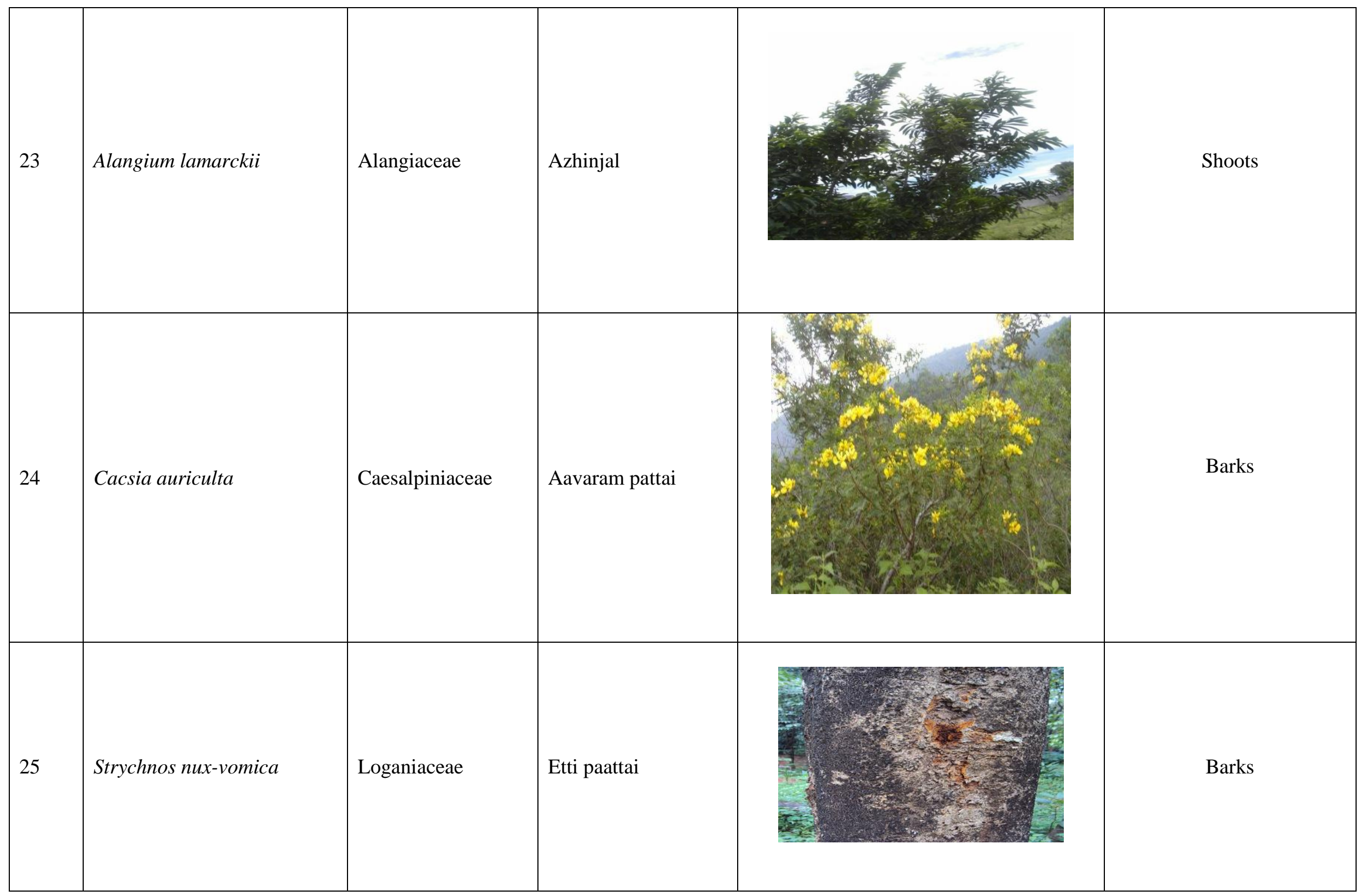


Int.J.Curr.Microbiol.App.Sci (2018) 7(7): 425-438

\begin{tabular}{|l|l|l|l|l|l|}
\hline 26 & Luffa acutangula & Cucurbitaceae & $\begin{array}{l}\text { Paambu peerkankai } \\
\text { panchu }\end{array}$ \\
\hline 27 & Andrographis paniculata & Acanthaceae & Siriyanangai & Fruits \\
\hline
\end{tabular}


The bitter taste of some leaves and roots are also sometimes used for prognostic purposes (Whitaker, 1978; Al-Qura'n, 2005). If the plant material tastes bitter, the patient is judged free from danger, but if the materials were sweet to the taste, the patient needs urgent medical attention. Dosages were repeated until the taste returns to normal. Sometimes, especially when a patient cannot open his/her mouth, the juice of the plant is administered through nostrils or eyes, or applied liberally to the head (Anandan and Veluchamy, 1986; Anuradha et al., 1986). A strict and complete dietary schedule for swelling, nausea, pain, and other effects during and after recovery is followed to promote a thorough cure (Whitaker, 1978).

Mimosa pudica has been reported to possess anti-hyaluronidase activity against Naja naja, and Vipera russelli (Girish and Kemparaju, 2007).

Samy et al (2008) indicated in their study that Strychnos nux-vomica, Aristolochia indica, Azadirachta indica, Hemidesmus indicus and Rauvolfia serpentina fractions neutralize krait venom activities in animal models. This is in accordance with the findings of this study.

The present study brought to light the immense hidden knowledge of Tribal people on poisonous bites of Naja naja, Bungarus fasciatus, and Bungarus caeruleus. They have been employing all these plants in the form of paste, powder, juice, decoction, infusion and also in crude form. Some of these tribal villages claim no deaths of snake bites, till date, by administering their ethnic medicines.

Rauvolfia tetraphylla leaf is being used for treating snake bites. This is in accordance with the findings of Dey and De, 2012.

The bark powder of Moringa oleifera is believed to have anti-snake properties if sprinkled near the house to ward off snakes (Chandra et al., 1989).

In conclusion, traditional medicine remains an integral part of the health system in this area Antidote medicinal plants play an important role in health and livelihood of Irula Tribal people. The above results deal with correlation between Distinctive epidemiologic and clinical features of common krait reported ethnobotanical uses of medicinal plants from different part of Kancheepuram district. The present study has revealed the authenticity of traditional knowledge of the irula tribals of Kancheepuram district.

\section{Acknowledgement}

We are thankful to Irula tribal Women Welfare Society, Thandarai for mobilizing the farmers in the village. We are thankful for the Irula tribal people who shared the information about the herbal remedies for snake bite. The authors are highly grateful to the Dean, Madras Veterinary College, Chennai and the Dean, Faculty of Basic Sciences, TANUVAS for permission and all logistic support to perform this "special Problem" as a part of PhD thesis.

\section{References}

Al-Qura'n, S., 2005. Ethnobotanical survey of folk toxic plants in southern part of Jordan. Toxicon. 46:119-129

Anandan, T., Veluchamy, G., 1986. Folk medical claims from Tamil nadu North Arcot district.Bulletin for Medical Ethnopharmacology and Botanical Research. 73: 99-109.

Anuradha, U., Kumbhojkar, MS., Vartak, VD., 1986. Observations on wild plants used in folk medicine in the rural areas of the Kolhapur district. Ancient Science of Life. 6: 119-121. 
Anita Jain, S.S. Katewa, S.K. Sharma, Praveen Galay, and Vartika Jain, 2011, Snakelore and indigenous snakebite remedies practiced by some tribal's of Rajasthan, Indian Journal of Traditional Knowledge, 10(2): 258268

Dey, A., and De, J. N. (2012). Traditional use of plants against snakebite in Indian subcontinent: A Review of the recent literature. African Journal of Traditional, Complementary and Alternative Medicines, 9(1), 153-174.

Girish, K. S., and Kemparaju, K. (2007). The magic glue hyaluronan and its eraser hyaluronidase: a biological overview. Life sciences, 80(21): 1921-1943.fr

Murugesan, M, V. Balasubramaniam and $\mathrm{H}$. Arthi, 2005, Ethno Medical Knowledge of Plants Used By Irula Tribes, Chengal Combai, the Nilgiris, Tamilnadu, Ancient Science of Life, 24(4):179 - 182

Opilli. 2009. Not a charmed life for snake catchers at work. The Hindu dated 69-2009 retrieved from http://www.thehindu.com/news/cities/ Chennai/article16004.ece

Prakash Rao, 2007. Herbal Medicine as Sustainable Livelihood: A Case of Irula Tribal Women Welfare Society from Rural India. Asia-Pacific Journal of Rural Development 27(2):87-100.
Revathi, R and T. Parimelazhagan, 2010. Traditional Knowledge on Medicinal plants used by the Irula tribe of Hasanur Hills, Erode District, Tamil Nadu, India, Ethnobotanical Leaflets 14: $136-160$

Samy, R. P., Thwin, M. M., Gopalakrishnakone, P., and Ignacimuthu, S. (2008). Ethnobotanical survey of folk plants for the treatment of snakebites in Southern part of Tamilnadu, India. Journal of Ethnopharmacology, 115(2), 302-312.

Snow, R.W., R. Bronzan, T. Roques, C. Nyamawi, S. Murphy, and K. Marsh. 1994. The prevalence and morbidity of snake bite and treatment-seeking behaviour among a rural Kenyan population. Annals of Tropical Medical Parasitology. 88:665-671.

Warrell, D. A. (1996). In Oxford Textbook of Medicine, Vol. 1, 3rd Edn., eds Weatherall, D. J., Ledingham, J. G. G. and Warrell, D. A. pp. 1124 \pm 1151 . Oxford: Oxford University Press.

Whitaker, R., 1978. Common Indian Snakes: A Field Guide. Macmillan India Ltd, p. 154.

Zaidi, MA., Crow, SA., 2005. Biologically active traditional medicinal herbs from Balochistan, Pakistan. Ethnopharmacol. 96: 331-334.

\section{How to cite this article:}

Senthilkumar, K., P. Mathialagan and Manivannan, C. 2018. Herbal Snake Bite Remedies of Irula Tribal People of Kancheepuram District, Tamil Nadu. Int.J.Curr.Microbiol.App.Sci. 7(07): 425-438. doi: https://doi.org/10.20546/ijcmas.2018.707.052 